\title{
Effect of cell size on tensile strength and elongation properties of honeycomb weave
}

\section{REZUMAT - ABSTRACT}

\section{Efectul dimensiunii celulei asupra rezistenței la tracțiune și a proprietăților de alungire a legăturii tip fagure}

Țesătura dezvoltată din legătura tip fagure este o țesătură multistrat având rezistență și alungire variabilă. Proprietățile acestor structuri depind de dimensiunea celulei legăturii de tip fagure. Scopul cercetării este de a identifica efectul dimensiunii celulei asupra rezistenței la tracțiune în ceea ce privește forța de rupere și alungirea structurilor cu legătură tip fagure. În această lucrare, au fost create și analizate trei dimensiuni de celule diferite, la țesături cu legătură tip fagure, atât în direcția urzelii, cât și în direcția bătăturii pentru determinarea proprietăților de rezistență la tracțiune. Analiza a evidențiat rezultate semnificative în direcția urzelii și a bătăturii țesăturilor cu legătură tip fagure.

Cuvinte-cheie: legătură tip fagure, țesătură multistrat, dimensiunea celulei, rezistență la tracțiune

\section{Effect of cell size on tensile strength and elongation properties of honeycomb weave}

The fabric developed from honeycomb weave is a multilayer fabric having variable strength and elongation. Properties of these structures depend on the cell size of the honeycomb weave. The aim of the research is to identify the effect of cell size on the tensile strength in terms of breaking force and elongation of the honeycomb weave structures. In this paper, three different cell sizes of honeycomb fabrics were created and analysed in both warp and weft direction for its tensile properties. Analysis shows significant results in the warp direction and weft direction of honeycomb fabric.

Keywords: honeycomb weave, multilayer fabric, cell size, tensile strength

\section{INTRODUCTION}

\section{D woven fabric - honeycomb fabric}

In 3D-fabric structures, the thickness or Z-direction dimension is significant compare to $X$ and $Y$ dimensions in which yarns are intertwined (braiding), interlaced (weaving) or intermeshed (knitting) in the $X$ (longitudinal), $Y$ (cross), and Z (vertical) directions [1]. 3-dimensional woven fabrics can be classified as hollow and firm/solid depending on the applications [2-4]. As the name suggests the composites from solid structures are single solid body like a solid plate having 3 dimensions i.e. length, width, and thickness. These types of structures include angle-interlock and orthogonal weave pattern or structures depending on the characteristics required. While in case hollow structures the fabric consists of one or more layers of triangular, trapezoidal or hexagonal cross-sectional shapes which are self-opening. The honeycomb structure is defined as the number of hexagonal ring structures which are arranged orderly in regular pattern [5] as shown in figure 1.

In current study, a woven honey-comb structure in weft direction is defined. Honeycomb structure can be represented as equation 1 :

$$
a L(b+c) P \theta
$$

Where in equation $1, a$ is number of fabric layers used to form the honeycomb structure and its value is always greater than and equal to 2; b - length of the bonded wall measured in the number of picks and

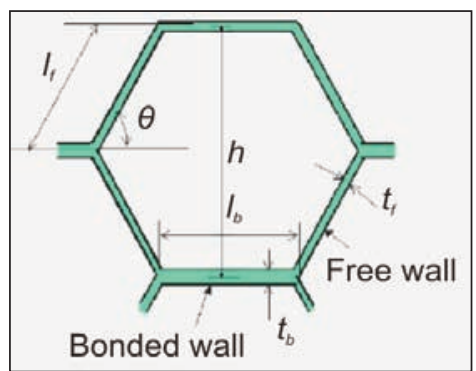

Fig. 1. Parameters of single honeycomb cell [5]

$\Theta$ is opening angle, $I_{b}$ - bonded wall lengthin $\mathrm{mm}$ $I_{f}$ - free wall length in $\mathrm{mm}, t_{b}$ - bonded wall thickness, $t_{f}$ - free wall thickness in $\mathrm{mm} \& h-$ height of cell in $\mathrm{mm}$

its value is always greater and equal to 1 ; by increasing the value if $b$ the length of the bonded wall $s$ increases; c - length of free wall measured in the number of picks and its value is always greater and equal to 1; by increasing the value if $c$ the length of the free wall $s$ increases; $\theta$ - the opening angle of the hexagonal cells which varies from $0^{\circ}$ to $90^{\circ}$; $\mathrm{L}$ is used to represent the 'layer'; $P$ is used to represent the 'pick'. If the number of picks in the bonded wall and number of picks in the free wall are equal, then the structure can be represented as in equation 2 .

$$
\text { aLbP } \theta
$$

In order to reduce the coding format (since $b=c$ ). According to the representation discussed above, a 2L1P60 honeycomb structure stands for a structure 


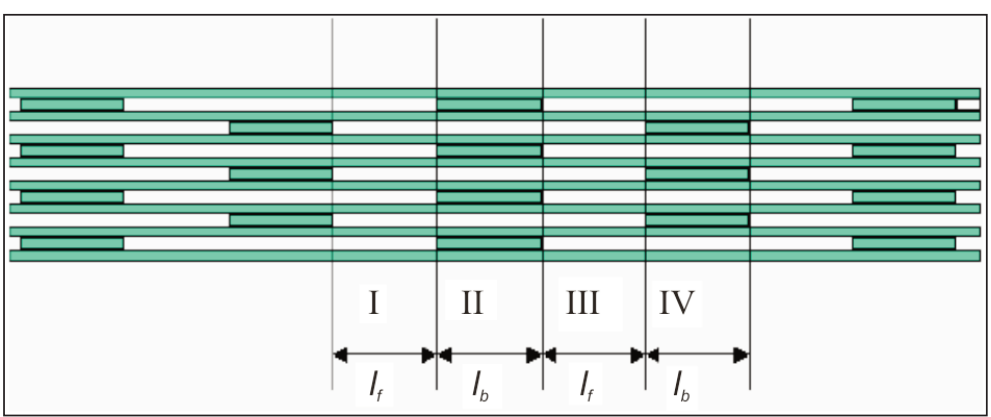

a

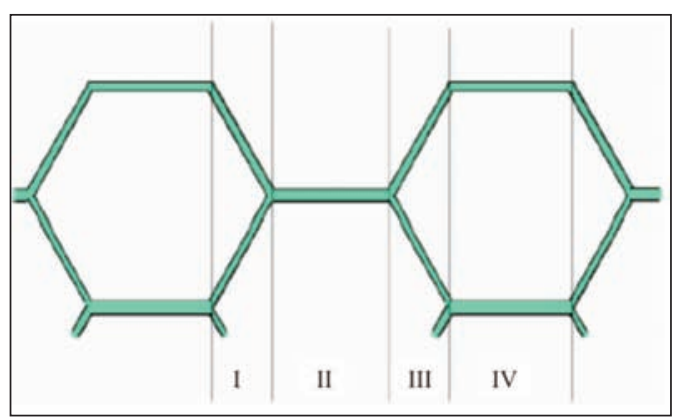

b

Fig. 2. Region division of a honeycomb structure: $a$ - before opening; $b$ - after opening [5]

having 2 layers of fabric, 1 pick in the length of free and 1 pick length of bonded walls and the opening angle is $60^{\circ}$. Moreover for example 4L3P45 denotes a honeycomb structure made from 4 layers of fabric, where there are 3 picks in length of free and bonded walls with the opening angle being $45^{\circ}$. On the other hand, $6 \mathrm{~L}(3+2) \mathrm{P}$ refers to a honeycomb structure made from 6 layers of fabric, where there are 3 picks and 2 picks in the lengths for the bonded and free walls respectively.

\section{Core of 3 dimensional honeycomb weaves}

For designing the regular and continuous hexagonal pattern with weaving the single unit of repeating region can be divided into 4 parts. They are regions I, II, III and IV, as shown in figure 2.

Region I corresponds to the part of the 3 dimensional honeycomb in which all fabric layers are separated from each other. Region II is the part where the adjacent layers join together at an alternate interval. Region III is the part which is same as Region I. Region IV is the joining part but the joining layers are different from that in Region II. The honeycomb structure is achieved after the opening of the honeycomb fabric.

Honeycomb weave is used in fabric where moisture absorption properties are required like hand towels, glass cloths, dispensed roller towels and bath mats, it is also used for quilt, soft furnishings, PPE (Personal Protective Equipment), automobile, aerospace. In composite structures honeycomb fabrics plays a vital role in energy absorption properties.

\section{EXPERIMENTAL WORK}

Weaving of honeycomb on a conventional loom Hollow CAD software is used to generate lifting plan of larger and complex structure. Following 2L1P structure will give more understanding towards the principle of the weave generation.

\section{The 2L1P structure}

It is simplest structure of honeycomb weave and can easily be understood as compared to other structure because it has only two layers and one pick in the free and bonded wall. For the creation of the any honeycomb structure there are three steps. Firstly, draw the structure as shown in figure 3. Secondly, draw the

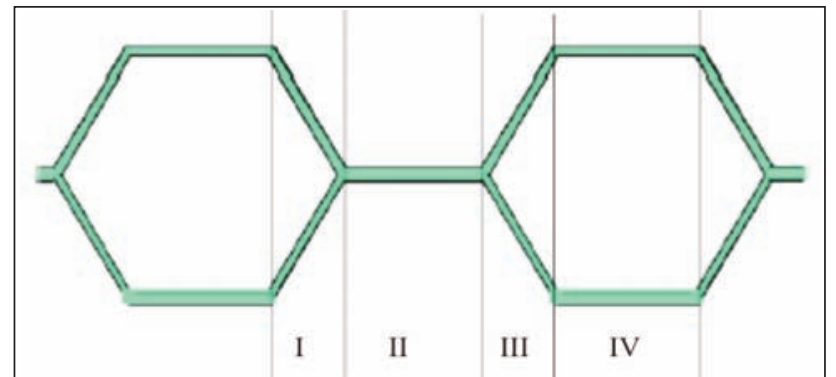

Fig. 3. Opened structure of $2 \mathrm{~L} 1 \mathrm{P}$ structure with marked regions [5]

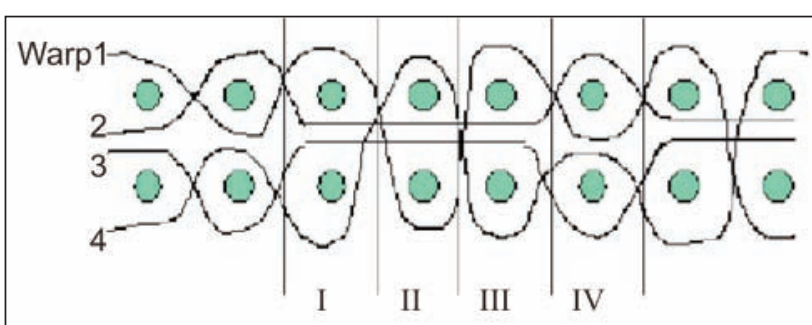

Fig. 4. Warp profile of 2L1P structure [5]

warp profile and mark the regions on the single repeated region as shown in figure 4 . Lastly, generate the Lifting plans as shown in figure 5 .

\section{Explanation}

These steps are explained and performed in a previously determined sequence:

1. The drawing structure is basically the opened structure of the honeycomb fabric

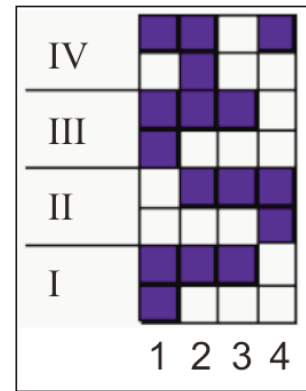

Fig. 5. Lifting plan of 2L1P structure [5] and can easily be drawn without any difficulty since $2 \mathrm{~L} 1 \mathrm{P}$ structure has two layers as shown in figure 3 .

2. The drawing of the warp profile of the given structure should be done with the proper visualization in mind as shown in figure 4.

3. For creating the lifting plan, there are 4 warp ends. Ends 1 and 2 are necessary for weaving top layer and the ends 3 and 4 are for bottom layer. Complete repeat comprised of four sections (I, II, III and IV), 
which repeat along the warp direction. For understanding take warp end 1 for the explanation of weave development. In section I, warp end 1 goes above the two picks as shown in figure 5 . When this warp end travels into region II, it went beneath both picks an in figure indicated as blank grids. In section III, warp ends travel above the 2 picks again. In the final section, this warp end is underneath the pick for the top layer but above the one for the bottom layer. Similarly, other weave diagram is completed accordingly.

\section{Lifting plans for fabric manufacturing}

The lifting plan for the weaving is defined as the representation of the pattern or design that provides information of raising and lowering the heddle frames. The lifting of the honeycomb multilayered fabric developed with the help of the Hollow CAD software.

\section{Structure on hollow CAD}

The hollow CAD software is used to design honeycomb multilayered fabric [6]. There is wide range of customization of honeycomb parameters for example: Angle, Bonded and free wall length, no of layers, type of weave. Figure 6 shows the 4-layer honey-

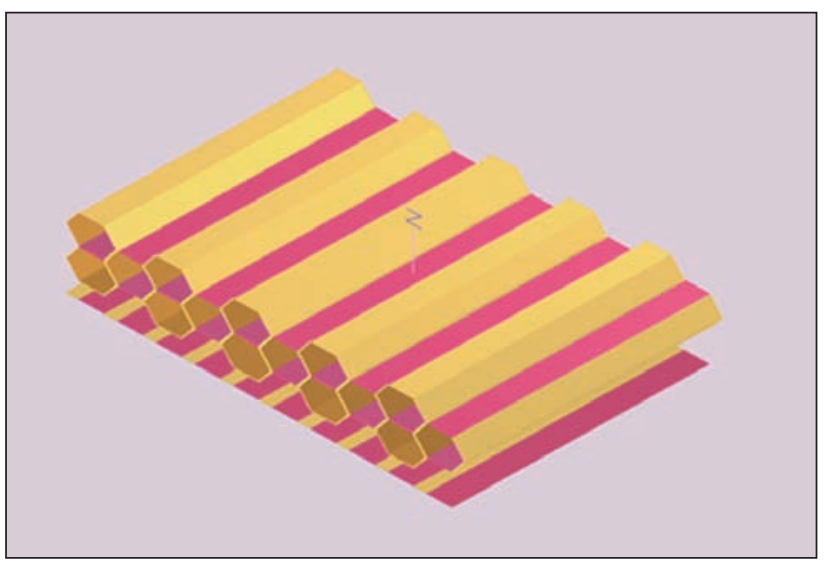

Fig. 6. Main screen of hollow CAD software comb structure. In this paper, the lifting plans of $4 \mathrm{~L} 6 \mathrm{P}$, 4L9P and 4L36P are used.

\section{Lifting plan of 4L6P, 4L9P \& 4L36P}

The blue mark indicates warp-up mark while white mark indicates warp-down mark. The lifting plan of structures show in: 4L6P in figure 7, a, 4L9P in figure $7, b \& 4 \mathrm{~L} 36 \mathrm{P}$ in figure $7, c$.

\section{Preparation of samples according to lifting plans}

\section{Sample \# 1}

The sample \# $14 \mathrm{~L} 6 \mathrm{P}$ honeycomb fabric is manufactured on the modified handloom. According to the lifting plan of the particular structure raising and lowering of the frames can be done manually. The structure sample is compact having very small cell size.

\section{Sample \# 2}

The sample \# 2 4L9P honeycomb fabric is manufactured on the modified handloom. According to the lifting plan of the particular structure raising and lowering of the frames can be done manually. The cell size of sample \# 2 is slightly larger thus easier to open as compared to sample \# 1.

\section{Sample \# 3}

The sample \# 3 4L36P honeycomb fabric is manufactured on the modified handloom. According to the lifting plan of the particular structure raising and lowering of the frames can be done manually. The cell size of sample \# 3 is largest among all the samples and very easy to open due to larger cell area as shown in figure 8.

\section{Manufacturing of honeycomb weave structures}

A handloom was used to manufacture the honeycomb fabric. The handloom should at least have double the number of heddle frames as per the number of layers. Each layer of honeycomb fabric required two headle frames. There are 8 heddle frames required for manufacturing the honeycomb fabric of 4 layers. The machine present in the NED University fabric manufacturing laboratory has been modified and fabric samples of 4L6P, 4L9P and 4L36P were

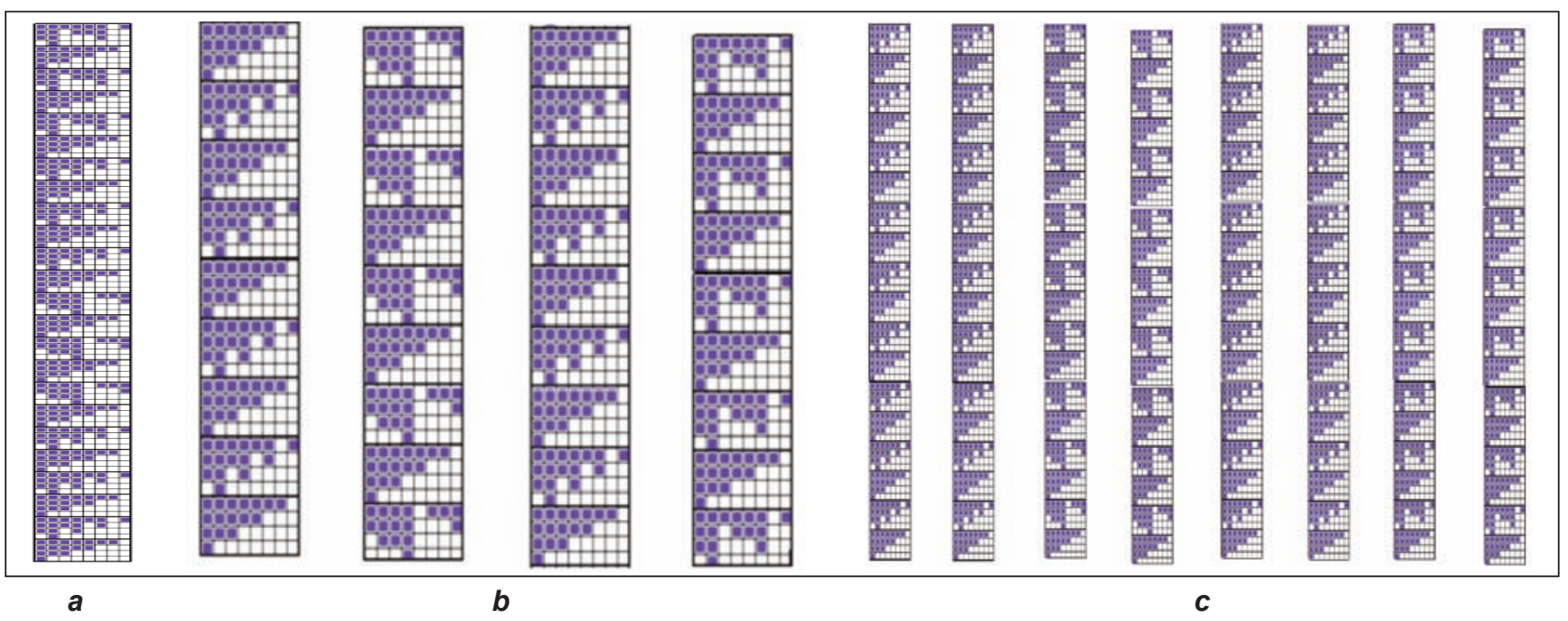

Fig. 7. $a$ - Lifting plan of 4L6P structure; $b$ - lifting plan of 4L9P structure; $c$ - lifting plan of 4L6P structure 


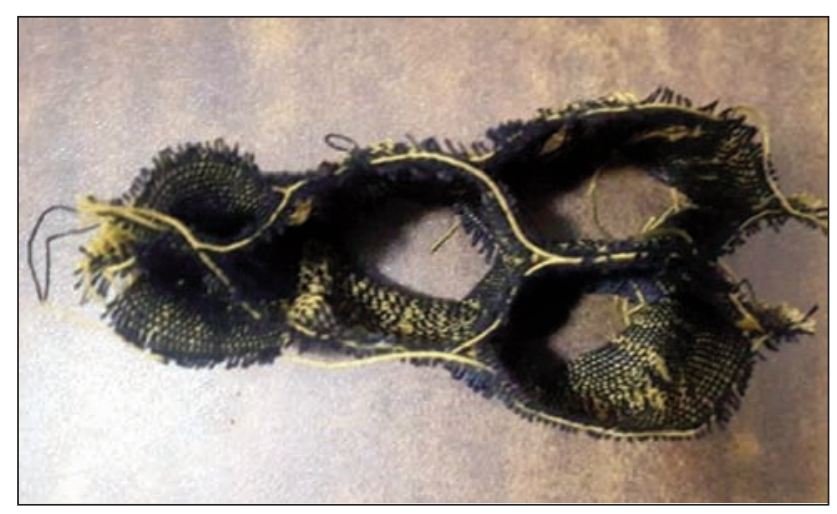

Fig. 8. 4L36P in open form

manufactured. 20/s 3-ply polyester yarn (commonly available in the market) is used in throughout all the samples and similar machine settings were used to manufacture all the honeycomb fabrics. In this manuscript as the analysis is only for distinct cell sizes that is why only one type of available yarn having $55.13 \mathrm{cN} /$ tex in all kind of developed structures. The honeycomb fabrics are designed to have four fabric layers. In all cases, it was decided that each layer of fabric will have a warp and weft density of 20 picks/inch. The warp and weft density of the overall honeycomb fabric can be calculated by multiplying the number of layers to the warp and weft density per layer. i.e. $\left(4^{*} 20\right)=80$ picks per inch.

Length of each wall of honey comb fabric should be measure through Vernier caliper in order to get real values. Although it can also be calculated by using simple logic and formulae as shown below

\section{Length of single cell wall $=$ (No. of picks}

in each cell wall/Pick per Inch per layer)

For example, in case of:

- $4 \mathrm{~L} 6 \mathrm{P}=(6 / 20)$ inches

- $4 \mathrm{~L} 9 \mathrm{P}=(9 / 20)$ inches

- $4 \mathrm{~L} 36 \mathrm{P}=(36 / 20)$ inches

\section{RESULTS AND DISCUSSION}

Three types of sample have been tested for tensile as per ASTM standard. Namely; 4L6P, 4L9P\&4L36P. All three sample types have 4 layers and are made from the same count and same threads but having different number of picks in each of the cell wall of honeycomb fabric which tends to increase the cell size. So the aim of this manuscript is to identify the properties by increasing the cell size and to analyze the test results of the multilayered honeycomb fabric of different cell size.

\section{Evaluation and analysis}

All three samples are tested for tensile in both warp and weft direction according to ASTM D5034 standard [7]. ASTM D 5034 is the Standard Test Method for Breaking Strength and Elongation of Textile Fabrics which is used to determine the breaking strength and elongation of woven, non-woven and felted fabrics.

Samples from the manufactured pieces of fabrics are cut in the warp direction according to the ASTM D5034 and tested for breaking elongation and breaking force. The data obtained in warp direction are shown in table 1.

\section{Graphical representation for breaking force \& elongation for warp}

The data represents in figure 9 , a, as the cell size of the fabric is increases tends to increase the percentage elongation in warp direction. The possible reason for this trend is that the stretching capability of the fabric of greater cell size is large as the no of joints between the layers is less in a unit length.

The data represents in figure $9, b$, as the cell size of the fabric is increases tends to increase the breaking force in warp direction. The possible reason for this trend is that as the fabric of greater cell size having maximum elongation tends resist more tensile stress as the time to bear stress is slightly increases.

Clearly trends can be in both breaking elongation breaking elongation.

Samples from the manufactured pieces of fabrics are cut in the weft direction according to the ASTM D5034 and tested for breaking elongation and breaking force. The data obtained in weft direction are shown in table 2.

\begin{tabular}{|c|c|c|c|c|c|}
\hline Sample type & $\begin{array}{l}\text { Breaking force }(\mathrm{N}) \\
\text { (warp direction) }\end{array}$ & $\begin{array}{c}\text { Average of } \\
\text { breaking force } \\
\text { (warp direction) }\end{array}$ & Sample type & $\begin{array}{c}\text { Breaking } \\
\text { elongation (\%) } \\
\text { (warp direction) }\end{array}$ & $\begin{array}{c}\text { Average of breaking } \\
\text { elongation } \% \text { (warp } \\
\text { direction) }\end{array}$ \\
\hline 4L6P1 & 2960.40 & \multirow{3}{*}{2598.03} & 4L6P1 & 38.35 & \multirow{3}{*}{34.27} \\
\hline 4L6P2 & 2441.40 & & 4L6P2 & 35.76 & \\
\hline 4L6P3 & 2392.30 & & 4L6P3 & 28.69 & \\
\hline 4L9P1 & 3213.50 & \multirow{3}{*}{2975.17} & 4L9P1 & 40.24 & \multirow{3}{*}{36.34} \\
\hline 4L9P2 & 2832.20 & & 4L9P2 & 39.92 & \\
\hline 4L9P3 & 2879.80 & & 4L9P3 & 28.85 & \\
\hline 4L36P1 & 2964.20 & \multirow{3}{*}{3241.93} & 4L36P1 & 39.51 & \multirow{3}{*}{39.10} \\
\hline 4L36P2 & 3151.60 & & 4L36P2 & 45.23 & \\
\hline 4L36P3 & 3610.00 & & 4L36P3 & 32.56 & \\
\hline
\end{tabular}




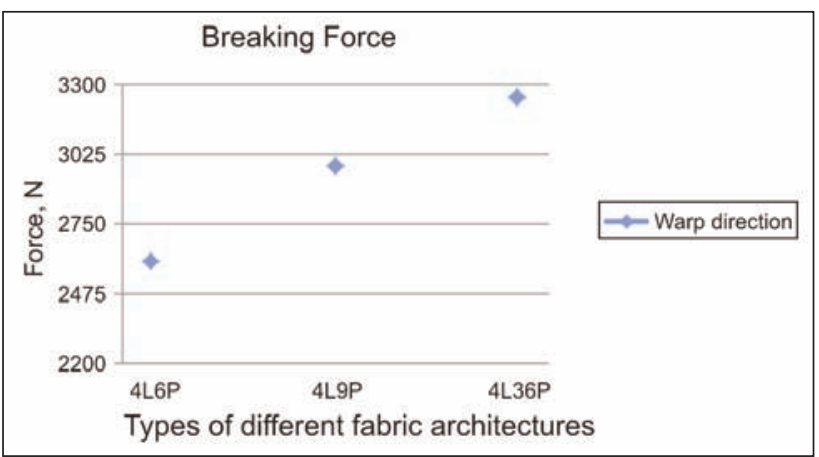

a

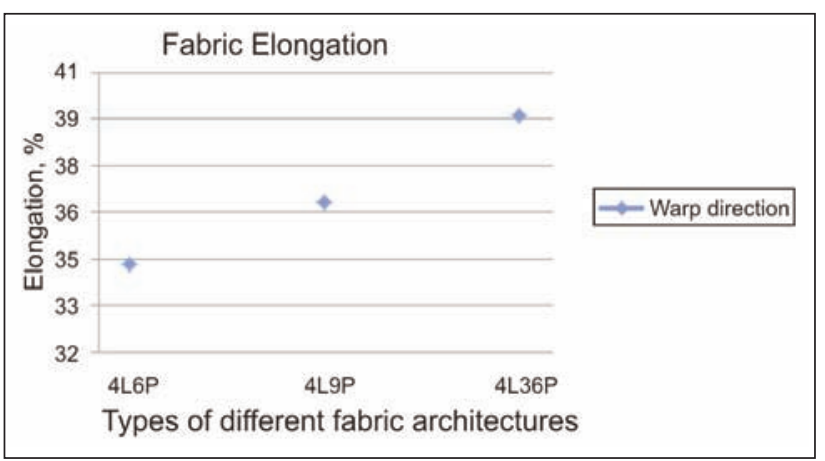

b

Fig. 9. Testing results in warp direction for: $a$ - breaking force; $b$ - fabric breaking elongation

\begin{tabular}{|c|c|c|c|c|c|}
\hline Sample type & $\begin{array}{l}\text { Breaking force }(\mathrm{N}) \\
\text { (weft direction) }\end{array}$ & $\begin{array}{c}\text { Average of } \\
\text { breaking force } \\
\text { (weft direction) }\end{array}$ & Sample type & $\begin{array}{c}\text { Breaking } \\
\text { elongation (\%) } \\
\text { (weft direction) }\end{array}$ & $\begin{array}{c}\text { Average of breaking } \\
\text { elongation } \% \text { (weft } \\
\text { direction) }\end{array}$ \\
\hline 4L6P1 & 1689.30 & \multirow{3}{*}{1533.30} & 4L6P1 & 27.00 & \multirow{3}{*}{24.70} \\
\hline 4L6P2 & 1696.50 & & 4L6P2 & 26.06 & \\
\hline 4L6P3 & 1214.10 & & 4L6P3 & 21.04 & \\
\hline 4L9P1 & 1706.70 & \multirow{3}{*}{1563.73} & 4L9P1 & 28.48 & \multirow{3}{*}{26.63} \\
\hline 4L9P2 & 1734.70 & & 4L9P2 & 30.17 & \\
\hline 4L9P3 & 1249.80 & & 4L9P3 & 21.25 & \\
\hline 4L36P1 & 1899.20 & \multirow{3}{*}{1738.40} & 4L36P1 & 27.24 & \multirow{3}{*}{27.17} \\
\hline 4L36P2 & 1688.80 & & 4L36P2 & 25.55 & \\
\hline 4L36P3 & 1627.20 & & 4L36P3 & 28.70 & \\
\hline
\end{tabular}

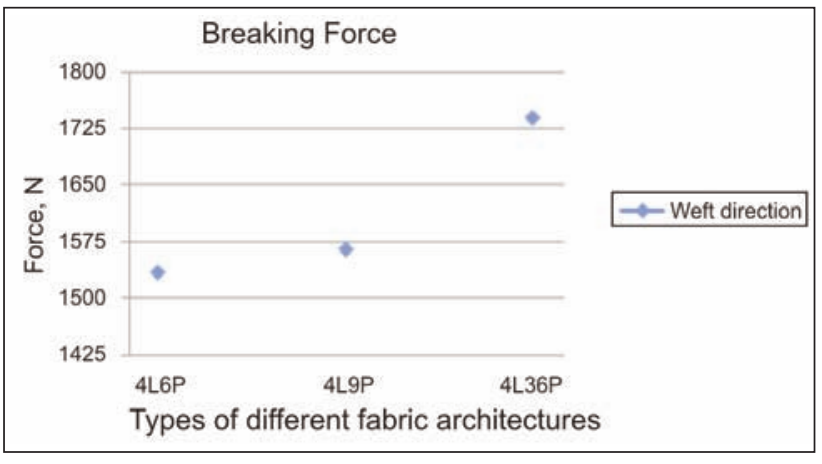

a

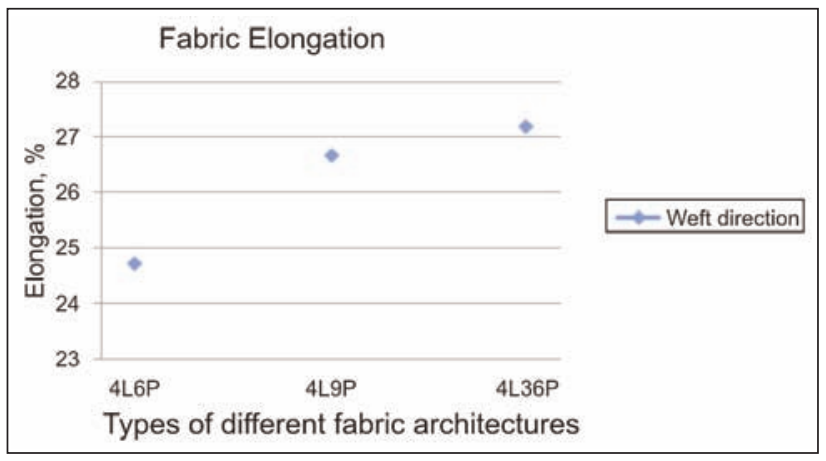

b

Fig. 10. Testing results in weft direction for: $a$ - breaking force; $b$ - fabric breaking elongation

\section{Graphical representation for breaking force \& elongation for weft}

The data represents in figure $10, a$, as the cell size of the fabric is increases the percentage elongation in weft direction also increases. The data represents in figure $10, b$, as the cell size of the fabric is increases the breaking force in weft direction also increases. Similar trend is seen in weft direction for both breaking force and breaking elongation.

\section{CONCLUSION}

The honeycomb multilayer fabric is tested in both weft and warp direction for breaking force and percentage elongation.
It is observed that breaking force and elongation percentage values is increased in warp and weft direction by increasing the cell size of honeycomb fabric. The possible reason for this trend is that fabric of greater cell size having maximum elongation tends to resist more tensile stress as the number of stitch between all the four layers decreases.

To be concluded that as the cell size of the fabric is increases, it increases percentage elongation and breaking force of the fabric.

\section{FUNDING/AKNOWLEDGEMENT}

Acknowledgement for NEDUET, Karachi, Pakistan.

Moreover, textile engineering students whose names are Shakeel Khatri, Usama Bin Taj, Muhammad Suleman, Hira Fatima are acknowledge for their efforts in their bachelor of engineering project. 


\section{BIBLIOGRAPHY}

[1] Gurkan, P. 3D Woven fabrics, In: Woven Fabrics. 2012.

[2] Chen., X. Mathematical and mechanical modelling of $3 D$ textile composites for protection against trauma impact, 2010.

[3] Tan, X., Xiaogang Chen, Jian Wang, Modelling energy absorption in textile composite cellular structures, 2008.

[4] Bagherpour, S. Fibre reinforced polyester composite, 2012.

[5] Gong, X. Investigation of different geometric structure parameter for honeycomb textile composites on their mechanical performance, 2011

[6] X. Chen, A.G. 3D honeycomb textile composites for impact protection, In: International Fiber Conference: Extreme and Aesthetic Textiles, Seoul, Korea, 2006. pp. 111-112.

[7] ASTM, ASTM D5034: Standard Test Method for Breaking Strength and Elongation of Textile Fabrics (Grab Test), 2017.

\section{Authors:}

BILAL ZAHID ${ }^{1}$

HAFSA JAMSHAID ${ }^{2}$

ABDUL WAQAR RAJPUT ${ }^{3}$

MOHAMAD FAIZUL YAHYA ${ }^{4}$

SHAKEEL KHATRI ${ }^{1}$

${ }^{1}$ Textile Engineering Department, NED University of Engineering and Technology,

Karachi - 75270, Sindh, Pakistan

${ }^{2}$ Department of Knitting, National Textile University Faisalabad, Pakistan

${ }^{3}$ Technical Textile Research Group, BZU College of Textile Engineering, Multan, Pakistan

${ }^{4}$ Textile Research Group, Faculty of Applied Sciences, Universiti Teknologi MARA, 40450 Shah Alam, Selangor, Malaysia

e-mail: drbilalzahid@neduet.edu.pk; hafsa@ntu.edu.pk; waqar.rajput@bzu.edu.pk; mfy@salam.uitm.edu.my; shakeelmarif@hotmail.com

\section{Corresponding author:}

ABDUL WAQAR RAJPUT

e-mail: waqar.rajput@bzu.edu.pk 